\title{
VERIFICATION OF A SURVEY OF THE MOST VALUABLE TREES IN THE CITY OF CZĘSTOCHOWA
}

\author{
Kacper Lechowicz, Dorota Wrońska-Pilarek, Zenon Pilarek, Magdalena Janyszek
}

\author{
K. Lechowicz, student of Forest Faculty, Poznań University of Life Sciences, Wojska Polskiego 28, 60-637 \\ Poznań, Poland, e-mail: kacper.91.lechowicz@interia.pl \\ D. Wrońska-Pilarek, Department of Forest Botany, Poznań University of Life Sciences, Wojska Polskiego 71 E, \\ 60-625 Poznań, Poland, e-mail: pilarekd@up.poznan.pl \\ Z. Pilarek, Department of Forest Technology, Poznań University of Life Sciences, Wojska Polskiego 71 C, \\ 60-625 Poznań, Poland, e-mail: zpilarek@up.poznan.pl, \\ M. Janyszek, Department of Botany, Poznań University of Life Sciences, Wojska Polskiego 71 C, 60-625 \\ Poznań, Poland, e-mail: carexmag@up.poznan.pl
}

(Received: September 30, 2016. Accepted: December 21, 2016)

\begin{abstract}
AвSTRAct. In the city of Częstochowa a total of 122 valuable trees of 25 species from 12 families were inventoried. The most numerous group comprises trees with circumferences of natural monuments (55), followed by already registered natural monuments (25), trees with circumferences comparable to those of natural monuments and impressive trees (18 specimens each) and the category of "other trees" (6). The status of natural monuments presently found in the city of Częstochowa was confirmed. Described trees are typically native deciduous species, of which the most numerous are Acer platanoides (18 trees) and Tilia cordata (16 trees). Approximately $60 \%$ of them have circumferences from 201 to $300 \mathrm{~cm}$. The health condition of surveyed trees is usually very good (84\%). A total of 45 trees were selected with circumferences of natural monuments and characterised by a very good health condition, which may be proposed as worthy of protection as natural monuments.
\end{abstract}

KeY WORDs: natural monuments, most valuable trees, dendrological survey, Częstochowa

\section{INTRODUCTION}

As it was stated by KasprZAK $(2005,2011)$, trees as natural monuments are not only a source of natural science knowledge, supplying valuable information e.g. on tree dieback, succession of organisms, dendrology or acclimation of alien species, but they are also of great value in the promotion of history of their towns and regions. By naming them (e.g. Edward, Lech) they directly refer to legends and tales or historical facts commemorating owners of estates, reminding us of distinguished people for the region or science, while thanks to their old age they remind us of ancient times. They are an important element of outstanding landscape, park and garden layouts, as well as religious and municipal green areas (e.g. Niepodległości Avenue in Poznań). They commemorate religious events or saints (e.g. trees in St. Wojciech
Square in Gniezno). In present time natural monuments are specimens of esthetic value, also serving social and scientific, as well as biocenotic roles as the habitat for many organisms not only during their lifetime, but also after they die (HARABIN 1996, BuLIŃsKI 1999, GołąBek \& Aleksandrowicz 2004, Gutowski et al. 2004).

In Poland the number of natural monuments in 2014 was 36 417, including 29937 single trees, 3766 clusters of trees and 749 avenues (GUS... 2015). The greatest number of natural monuments is found in the Mazowieckie Province (4256), while it is lowest in the Opolskie Province (683). Over the years the numbers of tree clusters, boulders and avenues are increasing, while those of single trees and grottoes, rocks and caves are decreasing.

In the Śląskie province, where Częstochowa is located, there are 1539 natural monuments; nevertheless, in the city the number is only 19, including 18 
single trees and one avenue (http://www.czestochowa.pl... b.d.). In comparison to other cities it is very little, e.g. in Warszawa there are 466 trees - natural monuments, in Kraków it is 274 , while in Wrocław it is 109 (http://stat.gov.pl... b.d.).

Municipal green areas in Częstochowa, such as parks, squares, small green areas, street greens and other areas, cover an area of 296.2 ha, of which parks cover 143.7 ha, belts of street green - 111.1 ha, while squares, small green areas and currently neglected areas -41.4 ha. In the city there are two groups of municipal green. One of them are managed green areas (e.g. parks, small green areas, squares, etc.), while the other comprises areas of natural green, which are remnants of former natural systems (KoWALEWSKi 1988, ZwolińsKi 1997, Dędek \& PaWlikowsKi 1999, http://www.czestochowa.pl... b.d.).

A survey of the most valuable trees was conducted in the most interesting municipal green areas in Częstochowa. They are two parks: the Stanisław Staszic Park of 5.45 ha and the 3 Maja Park covering 6.39 ha, situated at the foot of an elevation, on top of which the Jasna Góra cloister is situated (Kowalewski 1990). In the Stanisław Staszic Park we find a bower, an astronomical observatory, the Ore Mining Museum, a water reservoir and the monuments of Stanisław Staszic and Kazimierz Pułaski. There are approx. 1300 trees, mainly deciduous, which age is estimated at 100-150 years (KowALeWski 1990, Zygmunt 2009). The 3. Maja Park has tennis courts, a playground and the monuments of Stanisław Moniuszko and Stefan Policiński. There are approx. 1600 trees in the park, primarily native deciduous species, of which some reached the age of over 130 years (KowALEWsKi 1990, Zygmunt 2009). Another landmark is the monastery park of the Pauline order, surrounding the walls of the Jasna Góra monastery. It is composed of a southern and northern part, separated by the access road to the monastery. The park itself covers approx. 5 ha and is undulating with relatively large differences in elevation. The vegetation in the park comprises a rich tree stand, both broadleaf and coniferous, varying in height, habit and age. Apart from the old trees growing there since the time of park establishment, there are numerous young trees, either purposefully planted or self-sown. A vast majority are native species, although there are also specimens of alien provenance, e.g. Zelkova serrata. One of the most important elements in the park is connected with the Stations of the Cross, situated on the walls over their entire length (Furs 2012). The most valuable dendrological landmarks of the city include a birch avenue classified as a natural monument, situated in the city district of Częstochówka-Parkitka. It is approx. $2.5 \mathrm{~km}$ in length. The avenue comprises 385 Betula pendula trees, growing on both sides of the road pavement at Bialska Street. Some specimens reach over $230 \mathrm{~cm}$ circumference, while the oldest trees are estimated at 60 years (ŚwIDEREK 2007).

The aim of this study was to verify the list of natural monuments in the city of Częstochowa, but also to find new, valuable trees growing in that city, which would meet the requirements imposed on natural monuments. The analyses were undertaken, since the number of trees - natural monuments is surprisingly low for such a large town, as it is only 19. The location, number, dimensions and health condition of surveyed trees were determined, while also verifying whether existing natural monuments are properly tended and new trees worthy protection as natural monuments may be found.

\section{STUDY AREA}

Częstochowa is located on the Warta river, where three geographical mesoregions meet, i.e. the upland Wyżyna Częstochowska, the depression Obniżenie Górnej Warty and the upland Wyżyna Wieluńska. These mesoregions belong to the common subprovince of the upland Wyżyna Śląsko-Krakowska (KoNDRACKI 2011). The city of Częstochowa is a capital of the Częstochowa county, which is found in the Śląsk province (http://www.czestochowa.pl... b.d.).

In terms of the covered area and the population it is the $13^{\text {th }}$ city in Poland. Currently the area of Częstochowa is $160 \mathrm{~km}^{2}$ and it is limited by the geographical coordinates, $19^{\circ} 14^{\prime} \mathrm{E}, 19^{\circ} 01^{\prime} \mathrm{W}$; with the city population in 2014 amounting to approx. 231 thousand inhabitants (http://stat.gov.pl... b.d., http://www.czestochowa.pl... b.d.).

The city is surrounded by hills, Złota Góra from the east, the Kawie Góry from the north, Góra Błeszeńska from the south and Jasna Góra from the west (Zygmunt 2009). They are elevations of max. $300 \mathrm{~m}$ in height. The highest hill is Góra Ossona of $316.7 \mathrm{~m}$ a.s.l. Within the city limits absolute latitude is mostly $250-270 \mathrm{~m}$ a.s.l.; it is an area located at relatively low altitudes for an upland, containing numerous elements of the lowland landscape (AктUALIZACJA... 2010).

Analyses were conducted in 13, frequently the most valuable green areas located in various parts of the city (Fig. 1). They were urban parks, cemeteries, green areas around churches and street green. The most valuable trees were recorded in the 3 Maja park, the Stanisław Staszic park, the Pauline order monastery park, the Gabriel Narutowicz park, in the Saint Roch, the Evangelical Church of Augsburg Confession and Kule cemeteries, at the Saint Barbara church, the Łukasiński, Sabinowska and Zbyszka streets, as well as the birch avenue considered to be a natural monument and located at Bialska street and at the Czesław Niemen Promenade.

Częstochowa is situated in the temperate climate zone at an altitude of $261 \mathrm{~m}$ a.s.l. The mean monthly 


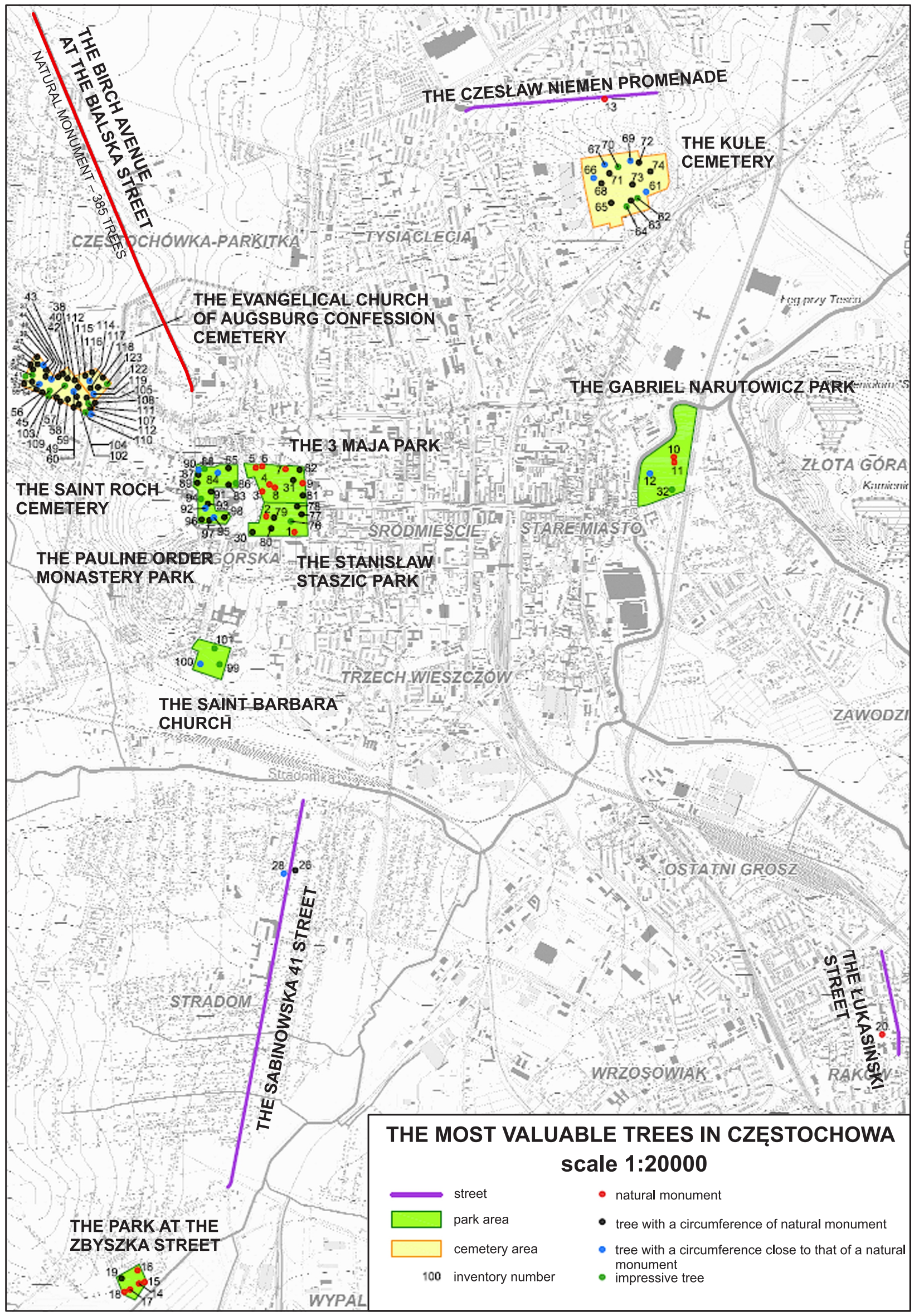

Fig 1. The most valuable trees in Częstochowa 
air temperature is approx. $7.8^{\circ} \mathrm{C}$, which is very close to the national mean. The annual amplitude of temperatures is approx. $21.8^{\circ} \mathrm{C}$. January is the coldest month with a mean temperature of $-3.4^{\circ} \mathrm{C}$, while July is the warmest month with a mean temperature of $18.4^{\circ} \mathrm{C}$. (http://www.czestochowa.pl... b.d.). The vegetation period is 221 days. The winter period typically begins around 20 November and lasts until the end of February. It is relatively long and with below zero temperatures. The mean period of snow cover is approx. 80 days. Precipitation with the annual mean total of approx. $600-700 \mathrm{~mm}$ to a limited degree exceed the national mean. There are few windless days in Częstochowa, with predominant westerly and south-westerly winds. Average annual wind velocity is $2.4 \mathrm{~m} / \mathrm{s}$ (http://www.czestochowa.pl... b.d.).

\section{MATERIAL AND METHODS}

The survey was conducted in the period from February to September 2015.

Data on the location of the most valuable trees were obtained from the register of natural monuments in Częstochowa and from studies describing the most valuable green areas in that city (KowALEWSKI 1990, SęTOWSKI 2005, 2006, Świderek 2007, Zygmunt 2009, Furs 2012, Rejestr... 2016, http:// www.czestochowa.pl... b.d.).

The scope of works included the determination of the geographical location (GPS) for each of the measured trees and recording of its survey number in order to prepare a map of the distribution of plants in the city of Częstochowa. The plants were identified to species. The nomenclature of taxa was adopted after Seneta \& Dolatowski (2011).

Works comprised measurements of tree circumferences at a height of $130 \mathrm{~cm}$ using a measuring tape accurate to $1 \mathrm{~cm}$. Trees coalesced at the base and forking above the height of $130 \mathrm{~cm}$ were treated as one specimen. In turn, specimens coalesced and forked below $130 \mathrm{~cm}$ were treated as separate specimens. Circumferences of natural monuments were adopted after the classification of RUCIŃSKI (1998). Three groups of the most valuable trees were distinguished: natural monuments (with circumferences of natural monuments), close to natural monuments (with circumferences by $10 \%$ smaller than those of natural monuments) and impressive (with circumferences by $20 \%$ smaller than those of natural monuments). All the inventoried trees are listed in a table (Table 1).

The health condition of inventoried plants was determined using two scales: according to KAMIŃsKI \& CzerniaK (2000) and ŁaKomy et al. (2008).

\section{RESULTS}

Within the city limits of Częstochowa a total of 122 impressive trees of 25 species, 18 genera and 12 fam- ilies were inventoried. They most frequently come from the families of Aceraceae (27\%) and Fagaceae and Tiliaceae (with $19 \%$ each; Table 1). The distribution of these trees is presented in the enclosed map (Fig. 1).

The most valuable trees are primarily broadleaved species $(80 \%$ - 20 species), rarely conifers (20\% - 5 species) - Abies concolor, Larix decidua, Pinus nigra, Thuja plicata, T. occidentalis (Table 1).

They are mostly native species - 15 (60\%), mainly maples, linden and oak trees (Table 1). A total of 10 alien species were recorded $(40 \%)$, with the largest number from North America - Abies concolor, Acer saccharinum, Liriodendron tulipifera, Quercus rubra, Thuja plicata and T. occidentalis, rarely from Europe - Aesculus hippocastanum and Pinus nigra, or Asia - Zelkova serrata. A common cultivar Salix $\times$ sepulcralis 'Chrysocoma' was also recorded (Table 1).

Among the most valuable trees the most numerous was Acer platanoides (18 specimens), with only one maple being a natural monument. Relatively often Tilia cordata is found (16), of which two linden trees are currently natural monuments, and Acer pseudoplatanus and Quercus robur (with 12 trees each). Ten species are represented by only one specimen (Table 1 ).

Among 122 impressive trees, 25 (18 single trees and 1 avenue being a natural monument, in which 7 birches with the greatest circumferences have dimensions of natural monuments) are currently recorded as natural monuments. It was established that 55 trees have circumferences of natural monuments, while 36 have circumferences close to those of natural monuments. Moreover, six other trees needs to be mentioned here, as they have exceptionally beautiful habits, although their circumference do not meet the criteria for natural monuments (Table 1).

Existing natural monuments include Betula pendula (7 trees), Quercus robur (4), Acer pseudoplatanus, A. saccharinum and Tilia cordata (with 2 trees each). The other natural monuments are represented by one specimen of a given species - Acer platanoides, Aesculus hippocastanum, Fraxinus excelsior, Larix decidua, Liriodendron tulipifera, Pyrus communis, Quercus rubra and Ulmus $\times$ hollandica. Trees with circumferences of natural monuments are most frequently representatives of Acer platanoides (13 trees), Tilia cordata (8) and Larix decidua and Acer pseudoplatanus (with 5 trees each). Among trees with circumferences close to those of natural monuments the most numerous are Acer pseudoplatanus (5) and Acer platanoides (3), while trees with impressive circumferences are most typically representatives of Tilia cordata (4 trees) and Fagus sylvatica ( 3 trees; Table 1 ).

Inventoried trees had circumferences ranging from $105 \mathrm{~cm}$ (Thuja occidentalis no. 42) to $426 \mathrm{~cm}$ (Quercus robur no. 17). Most of them (76-62.3\%) have circumferences of $201-300 \mathrm{~cm}$, by $50 \%$ fewer had circumferences of $301-400 \mathrm{~cm}(35-28.7 \%)$, while the smallest numbers were those of the thin- 
Table 1. A list of the most valuable trees inventoried in Częstochowa

\begin{tabular}{|c|c|c|c|c|c|c|c|}
\hline No & $\begin{array}{l}\text { Inventory } \\
\text { number }\end{array}$ & Species & Family & $\begin{array}{l}\text { Circumference } \\
\text { at the height } \\
\text { of } 1.3 \mathrm{~m}(\mathrm{~cm})\end{array}$ & $\begin{array}{l}\text { Health } \\
\text { condition }\end{array}$ & Locality & Status \\
\hline 1 & 17 & Quercus robur $\mathrm{L}$. & Fagaceae & 426 & 5 & the park at the Zbyszka street & PP \\
\hline 2 & 5 & Aesculus hippocastanum L. & Hippocastanaceae & 414 & 5 & the 3 Maja park & PP \\
\hline 3 & 11 & Acer saccharinum $\mathrm{L}$. & Aceraceae & 396 & 5 & the Gabriel Narutowicz park & PP \\
\hline 4 & 3 & Fraxinus excelsior L. & Oleaceae & 384 & 5 & the 3 Maja park & PP \\
\hline 5 & 13 & Ulmus $\times$ hollandica Mill. & Ulmaceae & 380 & 5 & $\begin{array}{l}\text { the Czesław Niemen Prome- } \\
\text { nade }\end{array}$ & PP \\
\hline 6 & 7 & Quercus rubra L. & Fagaceae & 364 & 5 & the 3 Maja park & PP \\
\hline 7 & 18 & Quercus robur L. & Fagaceae & 361 & 4 & the park at the Zbyszka street & PP \\
\hline 8 & 14 & Tilia cordata Mill. & Tiliaceae & 351 & 5 & the park at the Zbyszka street & PP \\
\hline 9 & 9 & Acer pseudoplatanus L. & Aceraceae & 350 & 4 & the 3 Maja park & PP \\
\hline 10 & 15 & Tilia cordata Mill. & Tiliaceae & $350 / 229$ & 5 & the park at the Zbyszka street & PP \\
\hline 11 & 4 & Quercus robur $\mathrm{L}$. & Fagaceae & 348 & 5 & the 3 Maja park & PP \\
\hline 12 & 16 & Quercus robur L. & Fagaceae & 348 & 5 & the park at the Zbyszka street & PP \\
\hline 13 & 10 & Acer saccharinum $\mathrm{L}$. & Aceraceae & 331 & 5 & the Gabriel Narutowicz park & PP \\
\hline 14 & 8 & Larix decidua Mill. & Pinaceae & 326 & 4 & the 3 Maja park & PP \\
\hline 15 & 6 & Acer platanoides L. & Aceraceae & 320 & 5 & the 3 Maja park & PP \\
\hline 16 & 1 & Acer pseudoplatanus L. & Aceraceae & 255 & 5 & the Stanisław Staszic park & PP \\
\hline 17 & 25 & Betula pendula Roth & Betulaceae & 255 & 5 & $\begin{array}{l}\text { the birch avenue at the Bialska } \\
\text { street }\end{array}$ & PP \\
\hline 18 & 23 & Betula pendula Roth & Betulaceae & 240 & 5 & $\begin{array}{l}\text { the birch avenue at the Bialska } \\
\text { street }\end{array}$ & PP \\
\hline 19 & 2 & Pyrus communis L. & Rosaceae & 238 & 5 & the Stanisław Staszic park & PP \\
\hline 20 & 20 & Liriodendron tulipifera $\mathrm{L}$. & Magnoliaceae & 236 & 1 & the Łukasiński street & PP \\
\hline 21 & 33 & Betula pendula Roth & Betulaceae & 230 & 5 & $\begin{array}{l}\text { the birch avenue at the Bialska } \\
\text { street }\end{array}$ & PP \\
\hline 22 & 35 & Betula pendula Roth & Betulaceae & 230 & 5 & $\begin{array}{l}\text { the birch avenue at the Bialska } \\
\text { street }\end{array}$ & PP \\
\hline 23 & 24 & Betula pendula Roth & Betulaceae & 218 & 5 & $\begin{array}{l}\text { the birch avenue at the Bialska } \\
\text { street }\end{array}$ & PP \\
\hline 24 & 22 & Betula pendula Roth & Betulaceae & 212 & 4 & $\begin{array}{l}\text { the birch avenue at the Bialska } \\
\text { street }\end{array}$ & PP \\
\hline 25 & 34 & Betula pendula Roth & Betulaceae & 198 & 5 & $\begin{array}{l}\text { the birch avenue at the Bialska } \\
\text { street }\end{array}$ & PP \\
\hline 26 & 56 & Tilia cordata Mill. & Tiliaceae & 405 & 3 & the Saint Roch cemetery & $\mathrm{P}$ \\
\hline 27 & 54 & Tilia cordata Mill. & Tiliaceae & 395 & 5 & the Saint Roch cemetery & $\mathrm{P}$ \\
\hline 28 & 73 & Quercus robur L. & Fagaceae & 391 & 5 & the Kule cemetery & $\mathrm{P}$ \\
\hline 29 & 80 & Aesculus hippocastanum L. & Hippocastanaceae & 355 & 5 & the Stanisław Staszic park & $\mathrm{P}$ \\
\hline 30 & 31 & Tilia cordata Mill. & Tiliaceae & 354 & 5 & the 3 Maja park & $\mathrm{P}$ \\
\hline 31 & 115 & Tilia cordata Mill. & Tiliaceae & $350 / 269$ & 5 & $\begin{array}{l}\text { the Evangelical Church of } \\
\text { Augsburg Confession cemetery }\end{array}$ & $\mathrm{P}$ \\
\hline 32 & 58 & Acer pseudoplatanus L. & Aceraceae & 350 & 3 & the Saint Roch cemetery & $\mathrm{P}$ \\
\hline 33 & 87 & Fagus sylvatica L. & Fagaceae & 350 & 5 & $\begin{array}{l}\text { the Pauline order monastery } \\
\text { park }\end{array}$ & $\mathrm{P}$ \\
\hline 34 & 19 & Quercus robur L. & Fagaceae & 347 & 4 & the park at the Zbyszka street & $\mathrm{P}$ \\
\hline 35 & 63 & Tilia cordata Mill. & Tiliaceae & 344 & 4 & the Kule cemetery & $\mathrm{P}$ \\
\hline 36 & 57 & $\begin{array}{l}\text { Quercus petraea (Matt.) } \\
\text { Liebl. }\end{array}$ & Fagaceae & 336 & 5 & the Saint Roch cemetery & $\mathrm{P}$ \\
\hline 37 & 77 & Quercus rubra L. & Fagaceae & 334 & 5 & the Stanisław Staszic park & $\mathrm{P}$ \\
\hline 38 & 46 & Fraxinus excelsior L. & Oleaceae & 332 & 5 & the Saint Roch cemetery & $\mathrm{P}$ \\
\hline 39 & 59 & Quercus robur $\mathrm{L}$. & Fagaceae & 327 & 5 & the Saint Roch cemetery & $\mathrm{P}$ \\
\hline 40 & 113 & Quercus rubra L. & Fagaceae & 327 & 5 & the Saint Roch cemetery & $\mathrm{P}$ \\
\hline 41 & 30 & Quercus rubra L. & Fagaceae & 326 & 5 & the Stanisław Staszic park & $\mathrm{P}$ \\
\hline 42 & 108 & Tilia cordata Mill. & Tiliaceae & 318 & 4 & the Saint Roch cemetery & $\mathrm{P}$ \\
\hline 43 & 72 & Acer platanoides $\mathrm{L}$. & Aceraceae & 312 & 5 & the Kule cemetery & $\mathrm{P}$ \\
\hline 44 & 79 & Acer platanoides L. & Aceraceae & 310 & 5 & the Stanisław Staszic park & $\mathrm{P}$ \\
\hline 45 & 102 & Quercus robur $\mathrm{L}$. & Fagaceae & 305 & 5 & the Saint Roch cemetery & $\mathrm{P}$ \\
\hline
\end{tabular}


Table 1 - cont.

\begin{tabular}{|c|c|c|c|c|c|c|c|}
\hline No & $\begin{array}{l}\text { Inventory } \\
\text { number }\end{array}$ & Species & Family & $\begin{array}{l}\text { Circumference } \\
\text { at the height } \\
\text { of } 1.3 \mathrm{~m}(\mathrm{~cm})\end{array}$ & $\begin{array}{l}\text { Health } \\
\text { condition }\end{array}$ & Locality & Status \\
\hline 46 & 107 & Tilia cordata Mill. & Tiliaceae & $304 / 205$ & 5 & the Saint Roch cemetery & $\mathrm{P}$ \\
\hline 47 & 60 & Tilia cordata Mill. & Tiliaceae & 300 & 5 & the Saint Roch cemetery & $\mathrm{P}$ \\
\hline 48 & 104 & Tilia platyphyllos L. & Tiliaceae & 295 & 5 & the Saint Roch cemetery & $\mathrm{P}$ \\
\hline 49 & 97 & $\begin{array}{l}\text { Zelkova serrata (Thunb.) } \\
\text { Makino }\end{array}$ & Ulmaceae & $290 / 225$ & 5 & $\begin{array}{l}\text { the Pauline order monastery } \\
\text { park }\end{array}$ & $\mathrm{P}$ \\
\hline 50 & 68 & Acer platanoides L. & Aceraceae & 290 & 5 & the Kule cemetery & $\mathrm{P}$ \\
\hline 51 & 91 & Pinus nigra J.F. Arnold & Pinaceae & 290 & 5 & $\begin{array}{l}\text { the Pauline order monastery } \\
\text { park }\end{array}$ & $\mathrm{P}$ \\
\hline 52 & 96 & Acer pseudoplatanus L. & Aceraceae & 288 & 5 & $\begin{array}{l}\text { the Pauline order monastery } \\
\text { park }\end{array}$ & $P$ \\
\hline 53 & 122 & Larix decidua Mill. & Pinaceae & 280 & 4 & $\begin{array}{l}\text { the Evangelical Church of } \\
\text { Augsburg Confession cemetery }\end{array}$ & $\mathrm{P}$ \\
\hline 54 & 71 & Larix decidua Mill. & Pinaceae & 279 & 5 & the Kule cemetery & $\mathrm{P}$ \\
\hline 55 & 74 & Larix decidua Mill. & Pinaceae & 278 & 5 & the Kule cemetery & $\mathrm{P}$ \\
\hline 56 & 98 & Larix decidua Mill. & Pinaceae & 277 & 5 & $\begin{array}{l}\text { the Pauline order monastery } \\
\text { park }\end{array}$ & $P$ \\
\hline 57 & 53 & Acer platanoides L. & Aceraceae & 275 & 5 & the Saint Roch cemetery & $\mathrm{P}$ \\
\hline 58 & 78 & Acer pseudoplatanus L. & Aceraceae & 265 & 5 & the Stanisław Staszic park & $\mathrm{P}$ \\
\hline 59 & 40 & Acer platanoides L. & Aceraceae & 265 & 4 & the Saint Roch cemetery & $\mathrm{P}$ \\
\hline 60 & 83 & Acer pseudoplatanus L. & Aceraceae & 260 & 4 & $\begin{array}{l}\text { the Pauline order monastery } \\
\text { park }\end{array}$ & $\mathrm{P}$ \\
\hline 61 & 82 & Fraxinus excelsior L. & Oleaceae & 257 & 5 & the 3 Maja park & $\mathrm{P}$ \\
\hline 62 & 85 & Acer campestre $\mathrm{L}$. & Aceraceae & 256 & 5 & $\begin{array}{l}\text { the Pauline order monastery } \\
\text { park }\end{array}$ & $\mathrm{P}$ \\
\hline 63 & 81 & Fraxinus excelsior $\mathrm{L}$. & Oleaceae & 255 & 5 & the 3 Maja park & $\mathrm{P}$ \\
\hline 64 & 44 & Acer platanoides $\mathrm{L}$. & Aceraceae & 252 & 5 & the Saint Roch cemetery & $\mathrm{P}$ \\
\hline 65 & 93 & Larix decidua Mill. & Pinaceae & 250 & 5 & $\begin{array}{l}\text { the Pauline order monastery } \\
\text { park }\end{array}$ & $\mathrm{P}$ \\
\hline 66 & 38 & Carpinus betulus L. & Betulaceae & 245 & 5 & the Saint Roch cemetery & $\mathrm{P}$ \\
\hline 67 & 51 & Acer platanoides L. & Aceraceae & 241 & 5 & the Saint Roch cemetery & $\mathrm{P}$ \\
\hline 68 & 105 & Acer pseudoplatanus L. & Aceraceae & 241 & 4 & the Saint Roch cemetery & $\mathrm{P}$ \\
\hline 69 & 65 & Acer platanoides L. & Aceraceae & 238 & 5 & the Kule cemetery & $\mathrm{P}$ \\
\hline 70 & 52 & Acer platanoides L. & Aceraceae & 233 & 5 & the Saint Roch cemetery & $\mathrm{P}$ \\
\hline 71 & 43 & Acer platanoides L. & Aceraceae & 231 & 4 & the Saint Roch cemetery & $\mathrm{P}$ \\
\hline 72 & 26 & Acer platanoides $\mathrm{L}$. & Aceraceae & 231 & 5 & the Sabinowska 41 street & $\mathrm{P}$ \\
\hline 73 & 50 & Acer platanoides L. & Aceraceae & 230 & 5 & the Saint Roch cemetery & $\mathrm{P}$ \\
\hline 74 & 89 & Acer platanoides L. & Aceraceae & 228 & 5 & $\begin{array}{l}\text { the Pauline order monastery } \\
\text { park }\end{array}$ & $P$ \\
\hline 75 & 118 & $\begin{array}{l}\text { Thuja plicata Donn ex D. } \\
\text { Don. }\end{array}$ & Cupressaceae & 220 & 5 & $\begin{array}{l}\text { the Evangelical Church of } \\
\text { Augsburg Confession cemetery }\end{array}$ & $P$ \\
\hline 76 & 48 & Carpinus betulus L. & Betulaceae & 218 & 5 & the Saint Roch cemetery & $\mathrm{P}$ \\
\hline 77 & 47 & Betula pendula Roth & Betulaceae & 215 & 5 & the Saint Roch cemetery & $\mathrm{P}$ \\
\hline 78 & 117 & $\begin{array}{l}\text { Thuja plicata Donn ex D. } \\
\text { Don. }\end{array}$ & Cupressaceae & 175 & 5 & $\begin{array}{l}\text { the Evangelical Church of } \\
\text { Augsburg Confession cemetery }\end{array}$ & $\mathrm{P}$ \\
\hline 79 & 116 & $\begin{array}{l}\text { Thuja plicata Donn ex D. } \\
\text { Don. }\end{array}$ & Cupressaceae & 168 & 5 & $\begin{array}{l}\text { the Evangelical Church of } \\
\text { Augsburg Confession cemetery }\end{array}$ & $\mathrm{P}$ \\
\hline 80 & 42 & Thuja occidentalis L. & Cupressaceae & 105 & 5 & the Saint Roch cemetery & $\mathrm{P}$ \\
\hline 81 & 119 & Aesculus hippocastanum L. & Hippocastanaceae & 295 & 5 & $\begin{array}{l}\text { the Evangelical Church of } \\
\text { Augsburg Confession cemetery }\end{array}$ & $\mathrm{Z}$ \\
\hline 82 & 61 & Tilia cordata Mill. & Tiliaceae & 295 & 5 & the Kule cemetery & $\mathrm{Z}$ \\
\hline 83 & 114 & Tilia platyphyllos L. & Tiliaceae & 291 & 5 & $\begin{array}{l}\text { the Evangelical Church of } \\
\text { Augsburg Confession cemetery }\end{array}$ & $\mathrm{Z}$ \\
\hline 84 & 92 & Tilia platyphyllos L. & Tiliaceae & 290 & 5 & $\begin{array}{l}\text { the Pauline order monastery } \\
\text { park }\end{array}$ & $\mathrm{Z}$ \\
\hline 85 & 55 & Tilia cordata Mill.. & Tiliaceae & 287 & 5 & the Saint Roch cemetery & $\mathrm{Z}$ \\
\hline 86 & 112 & Quercus robur $\mathrm{L}$. & Fagaceae & 286 & 0 & the Saint Roch cemetery & $\mathrm{Z}$ \\
\hline 87 & 84 & Fagus sylvatica L. & Fagaceae & 282 & 5 & $\begin{array}{l}\text { the Pauline order monastery } \\
\text { park }\end{array}$ & $\mathrm{Z}$ \\
\hline
\end{tabular}




\begin{tabular}{|c|c|c|c|c|c|c|c|}
\hline No & $\begin{array}{l}\text { Inventory } \\
\text { number }\end{array}$ & Species & Family & $\begin{array}{l}\text { Circumference } \\
\text { at the height } \\
\text { of } 1.3 \mathrm{~m}(\mathrm{~cm})\end{array}$ & $\begin{array}{l}\text { Health } \\
\text { condition }\end{array}$ & Locality & Status \\
\hline 88 & 69 & Aesculus hippocastanum L. & Hippocastanaceae & 279 & 5 & the Kule cemetery & $\mathrm{Z}$ \\
\hline 89 & 12 & $\begin{array}{l}\text { Salix } \times \text { sepulcralis 'Chryso- } \\
\text { coma' }\end{array}$ & Salicaceae & 273 & 4 & the Gabriel Narutowicz park & $\mathrm{Z}$ \\
\hline 90 & 49 & Quercus robur $\mathrm{L}$. & Fagaceae & 270 & 5 & the Saint Roch cemetery & $\mathrm{Z}$ \\
\hline 91 & 95 & Acer pseudoplatanus L. & Aceraceae & 260 & 5 & $\begin{array}{l}\text { the Pauline order monastery } \\
\text { park }\end{array}$ & $\mathrm{Z}$ \\
\hline 92 & 67 & Acer platanoides L. & Aceraceae & 222 & 5 & the Kule cemetery & $\mathrm{Z}$ \\
\hline 93 & 90 & Acer pseudoplatanus L. & Aceraceae & 221 & 5 & $\begin{array}{l}\text { the Pauline order monastery } \\
\text { park }\end{array}$ & $\mathrm{Z}$ \\
\hline 94 & 28 & Acer platanoides L. & Aceraceae & 220 & 5 & the Sabinowska 41 street & $\mathrm{Z}$ \\
\hline 95 & 37 & Acer pseudoplatanus L. & Aceraceae & 218 & 5 & the Saint Roch cemetery & $\mathrm{Z}$ \\
\hline 96 & 39 & Acer pseudoplatanus L. & Aceraceae & 215 & 4 & the Saint Roch cemetery & $\mathrm{Z}$ \\
\hline 97 & 66 & Acer platanoides L. & Aceraceae & 215 & 5 & the Kule cemetery & $\mathrm{Z}$ \\
\hline 98 & 100 & Acer pseudoplatanus L. & Aceraceae & 215 & 5 & the Saint Barbara church & $\mathrm{Z}$ \\
\hline 99 & 94 & Fagus sylvatica L. & Fagaceae & 269 & 5 & $\begin{array}{l}\text { the Pauline order monastery } \\
\text { park }\end{array}$ & $\mathrm{O}$ \\
\hline 100 & 45 & Aesculus hippocastanum L. & Hippocastanaceae & 267 & 5 & the Saint Roch cemetery & $\mathrm{O}$ \\
\hline 101 & 111 & Quercus robur $\mathrm{L}$. & Fagaceae & 266 & 5 & the Saint Roch cemetery & $\mathrm{O}$ \\
\hline 102 & 64 & Tilia platyphyllos L. & Tiliaceae & 266 & 5 & the Kule cemetery & $\mathrm{O}$ \\
\hline 103 & 88 & Fagus sylvatica $\mathrm{L}$. & Fagaceae & 266 & 5 & $\begin{array}{l}\text { the Pauline order monastery } \\
\text { park }\end{array}$ & $\mathrm{O}$ \\
\hline 104 & 110 & Tilia cordata Mill. & Tiliaceae & 265 & 5 & the Saint Roch cemetery & $\mathrm{O}$ \\
\hline 105 & 86 & Fagus sylvatica L. & Fagaceae & 265 & 5 & $\begin{array}{l}\text { the Pauline order monastery } \\
\text { park }\end{array}$ & $\mathrm{O}$ \\
\hline 106 & 76 & Quercus rubra L. & Fagaceae & 263 & 5 & the Stanisław Staszic park & $\mathrm{O}$ \\
\hline 107 & 32 & $\begin{array}{l}\text { Salix } \times \text { sepulcralis 'Chryso- } \\
\text { coma' }\end{array}$ & Salicaceae & 262 & 5 & the Gabriel Narutowicz park & $\mathrm{O}$ \\
\hline 108 & 99 & $\begin{array}{l}\text { Salix } \times \text { sepulcralis 'Chryso- } \\
\text { coma' }\end{array}$ & Salicaceae & 262 & 5 & the Saint Barbara church & $\mathrm{O}$ \\
\hline 109 & 41 & Aesculus hippocastanum L. & Hippocastanaceae & 257 & 5 & the Saint Roch cemetery & $\mathrm{O}$ \\
\hline 110 & 109 & Tilia cordata Mill. & Tiliaceae & 255 & 5 & In the Saint Roch cemetery & $\mathrm{O}$ \\
\hline 111 & 62 & Tilia cordata Mill. & Tiliaceae & 251 & 5 & the Kule cemetery & $\mathrm{O}$ \\
\hline 112 & 70 & Tilia cordata Mill. & Tiliaceae & 247 & 5 & the Kule cemetery & $\mathrm{O}$ \\
\hline 113 & 103 & Tilia platyphyllos $\mathrm{L}$. & Tiliaceae & 243 & 5 & the Saint Roch cemetery & $\mathrm{O}$ \\
\hline 114 & 101 & Quercus robur L. & Fagaceae & 241 & 5 & the Saint Barbara church & $\mathrm{O}$ \\
\hline 115 & 123 & Fraxinus excelsior $\mathrm{L}$. & Oleaceae & 210 & 5 & $\begin{array}{l}\text { the Evangelical Church of } \\
\text { Augsburg Confession cemetery }\end{array}$ & $\mathrm{O}$ \\
\hline 116 & 36 & Carpinus betulus L. & Betulaceae & 174 & 5 & the Saint Roch cemetery & $\mathrm{O}$ \\
\hline 117 & 75 & Populus alba L. & Salicaceae & 303 & 5 & the Kule cemetery & $\mathrm{PZ}$ \\
\hline 118 & 106 & Tilia platyphyllos $\mathrm{L}$. & Tiliaceae & $230 / 226 / 206$ & 5 & the Saint Roch cemetery & $\mathrm{PZ}$ \\
\hline 119 & 124 & Tilia platyphyllos L. & Tiliaceae & 230 & 5 & $\begin{array}{l}\text { the Evangelical Church of } \\
\text { Augsburg Confession cemetery }\end{array}$ & $\mathrm{PZ}$ \\
\hline 120 & 121 & Larix decidua Mill. & Pinaceae & 195 & 4 & $\begin{array}{l}\text { the Evangelical Church of } \\
\text { Augsburg Confession cemetery }\end{array}$ & $\mathrm{PZ}$ \\
\hline 121 & 120 & $\begin{array}{l}\text { Abies concolor (Gordon et } \\
\text { Glend.) Lindl. ex Hildebr. }\end{array}$ & Pinaceae & 172 & 5 & $\begin{array}{l}\text { the Evangelical Church of } \\
\text { Augsburg Confession cemetery }\end{array}$ & $\mathrm{PZ}$ \\
\hline 122 & 27 & Acer platanoides $\mathrm{L}$. & Aceraceae & 164 & 5 & the Sabinowska 41 street & $\mathrm{PZ}$ \\
\hline
\end{tabular}

Legend: PP - natural monument, $\mathrm{P}$ - tree with a circumference of a natural monument, $\mathrm{Z}$ - tree with a circumference close to that of a natural monument $(-10 \%), \mathrm{O}-$ impressive tree $(-20 \%)$, PZ - other tree, shaded - natural monument candidates.

nest specimens with circumferences of $101-200 \mathrm{~cm}$ $(8-6.6 \%)$ and the thickest of more than $401 \mathrm{~cm}$ in circumference $(3-2.5 \%)$. The thickest trees were two natural monuments, i.e. Quercus robur no. 17 with a circumference of $426 \mathrm{~cm}$ and Aesculus hippocastanum no. 5 with a circumference of $414 \mathrm{~cm}$, as well as one having the circumference of a natural monument $(405 \mathrm{~cm})$ - Tilia cordata no. 56 (Table 1).
Natural monuments (25 trees) have circumferences of $198-426 \mathrm{~cm}$. Values of $301-400 \mathrm{~cm}$ were recorded for 13 trees, while those of $201-300 \mathrm{~cm}$ were recorded for nine, only one tree measured less than $200 \mathrm{~cm}(198 \mathrm{~cm})$, wheras two specimens had circumferences of over $400 \mathrm{~cm}$ (Table 1).

The health condition of 122 inventoried trees is typically very good. As many as 103 of them (84.4\%) 
are absolutely healthy and do not require any tending operations, their crowns are appropriately developed with a slight share of dead branches. Observed trunk damage is small, sealing or already sealed, having no significant effect on the health condition of trees. As few as 15 specimens are in good condition and require only small tending interventions, consisting in the removal of dead branches. Trunk damage in those trees is of limited area, in the form of frost clefts or small hollows. Two Tilia cordata trees (nos. $56,58)$ from the Saint Roch Cemetery are of moderately good condition, which is manifested in a greater degree of crown die-back, observable signs of trunk fungal infestation, insect feeding or larger hollows. Liriodendron tulipifera (no. 20) growing at Łukasiński Street is the only tree in a very bad health condition. This tree is dying, most of its crown (approx. 60\%) is already dead, while in the butt end portion of the trunk numerous fruiting bodies of bracket fungi are observed. Although the tree poses no direct threat to the surrounding area, as it is growing at a considerable distance from the street, it should be properly protected. Quercus robur (no. 112) growing in Saint Roch Cemetery died for unspecified causes. It may have been trunk or root rot and in such a case an oak growing in the cemetery may constitute a serious hazard for people or a threat to property. It is necessary to obtain an expert assessment of the tree condition and make a decision on its removal (Table 1).

\section{CONCLUDING REMARKS}

As a result of a detailed survey conducted in the city of Częstochowa a total of 122 valuable trees were recorded, belonging to 25 species, coming from 12 families.

These trees are mostly native species (15), less frequently alien plants (10). Broad-leaved trees predominate (20 species), mainly maples, linden and oak trees, much less frequently they are coniferous species (5). Most trees (84\%) are in a very good health condition. However, it needs to be remembered that all natural monuments should be regularly monitored and tended, particularly those which are found in moderate or bad health condition (Table 1).

Inventoried trees have circumferences from 105 to $426 \mathrm{~cm}$. Most of them $(62.3 \%)$ measure from 201 to $300 \mathrm{~cm}$.

Among inventoried trees we need to distinguish three thickest, beautiful natural monument trees, i.e. Quercus robur, Aesculus hippocastanum and Acer saccharinum, with circumferences of 426, 414 and $396 \mathrm{~cm}$, respectively. Valuable and rare trees include Zelkova serrata coming from Asia, with trunk circumferences of 290 and $225 \mathrm{~cm}$, as well as Liriodendron tulipifera measuring $236 \mathrm{~cm}$, which unfortunately is in a bad health condition.
The largest number of trees are those with circumferences of natural monuments (55), with the lesser number of actual natural monuments (25) and trees with circumferences close to those of natural monuments and impressive trees (with 18 specimens each), while the lowest number comprises the so-called other trees (6).

This study confirmed the number of existing natural monuments reported in the register of natural monuments for the city of Częstochowa (Rejestr... 2016). Their population is currently 18 single trees and one birch avenue of 385 Betula pendula trees. The list of natural monuments in the form of single trees was supplemented with seven thickest birches with dimensions of natural monuments, growing in the natural monument avenue at Bialska Street.

Analysis of the presented results of this survey leads to a conclusion that at present the number of natural monuments in the city of Częstochowa is too small. For this purpose 45 single trees with circumferences of natural monuments and in a very good health condition were selected, which may be proposed to be protected as natural monuments (Table 1).

\section{ACKNOWLEDGEMENTS}

The authors would like to thank Mr. Sławomir Jończyk, Head of the Office of Nature and Urban Green Maintenance in the Department of Environmental Protection, Agriculture and Forestry of the Office of the city of Częstochowa for his kind assistance in the course of the conducted field studies.

\section{REFERENCES}

Aktualizacja Programu Ochrony Środowiska dla Miasta Częstochowy z uwzględnieniem lat 20102014 z perspektywą do roku 2017. (2010). Urząd Miasta Częstochowa, Częstochowa.

Buliński M. (1999): Pomnikowe drzewa i krzewy $\mathrm{w}$ nowoczesnej ochronie przyrody. Internetowy Magazyn Przyrodniczy Salamandra 10. http:// www.salamandra.org.pl/magazyn/b10a04.html (access: 21.12.2016).

Dędek J., Pawlikowski J. (1999): Częstochowa dla każdego. PP Oddział Prasa Śląska, Katowice-Częstochowa.

FuRs B. (2012): Jasnogórski park klasztorny: dzieje, kształt, znaczenie. Pro-Auto, Częstochowa.

Goząbek E., Aleksandrowicz M. (2004): Ocena wieku i stanu zdrowotnego drzew pomnikowych na Obszarze Chronionego Krajobrazu Bory Niemodlińskie. Studia i Monografie 350. Uniwersytet Opolski, Opole.

GUS. Ochrona środowiska 2015. (2015). Informacje i Opracowania Statystyczne, Warszawa. http://stat. gov.pl./obszary-tematyczne/srodowisko-energia/ 
srodowisko/ocrona-srodowiska-2015,1,16.html (access: 14.12.2016).

Gutowski J.M., Bobiec A., Pawlaczyk P., Zub K. (2004): Drugie życie drzewa. WWF Polska, WarszawaHajnówka.

HARABIN Z. (1996): Ochrona drzew pomnikowych w Polsce. Komunikaty Dendrologiczne 2/24: 5-12.

http://www.czestochowa.pl/page/385,tereny-zieleni-miejskiej-w-czestochowie.html (access:

http://stat.gov.pl/files/gfx/portalinformacyjny/ $\mathrm{pl} /$ defaultaktualnosci/5484/1/15/1/ochrona srodowiska_2015.pdf (access: 9.12.2016).

Kamiński B., Czerniak A. (2000): Badanie drzewostanów oraz sporządzenie opinii naukowej kwalifikującej do stworzenia wykazu inwentaryzacyjnego starych, cennych drzew na terenie miasta Poznania. Typescript. Katedra Inżynierii Leśnej Uniwersytetu Przyrodniczego w Poznaniu.

KASPRZAK K. (2005): Ochrona pomników przyrody. Zasady postępowania administracyjnego. Wydawnictwo Abrys, Poznań.

KASPRZAK K. (2011): Drzewa - pomniki przyrody i pamiątki kultury. Turystyka Kulturowa, 4: 17-38. www.turystykakulturowa.org. (access: 14.12.2016).

KondRACKI J. (2011): Geografia regionalna Polski. Wydawnictwo Naukowe PWN, Warszawa.

KowALEWSKI L. (1988): Parki, rezerwaty i pomniki przyrody województwa częstochowskiego. Wydawnictwo Naukowe Uniwersytetu im. Adama Mickiewicza, Poznań.

KowALEwSKI L. (1990): Przyroda parków pałacowych i dworskich na obszarze województwa częstochowskiego. Wyższa Szkoła Pedagogiczna w Częstochowie, Częstochowa.
ŁAKOMY P., Nowik K., Góral J. (2008): Stan zdrowotny drzew pomnikowych na terenie Wrocławia. Katedra Fitopatologii Leśnej Uniwersytetu Przyrodniczego w Poznaniu.

Rejestr Pomników Przyrody w województwie śląskim. (2016). Regionalna Dyrekcja Ochrony Środowiska. bip.katowice.rdos.gov.pl/files/artykuly/22381/pp.xls.

RuciŃSKI P. (1998): Motywy i kryteria uznawania tworów przyrody za pomniki. Las Polski 23: 7-10.

Seneta W., Dolatowski J. (2011): Dendrologia. Wydawnictwo Naukowe PWN, Warszawa.

SĘTOWski J. (2005): Cmentarz Kule w Częstochowie. Wydawnictwo im. Stanisława Podobińskiego, Częstochowa.

SĘTOWsKi J. (2006): Cmentarz ewangelicko-augsburski w Częstochowie. Muzeum Częstochowskie, Częstochowa.

ŚWIDEREK G. (2007): Parki i ogrody województwa śląskiego. Ośrodek Działań Ekologicznych „Źródła”, Łódź.

Zwoliński M. (1997): Przewodnik po Częstochowie. PTTK Oddział przy Hucie „Częstochowa”, Częstochowa.

Zygmunt J. (2009): Przewodnik po parkach miejskich 3. Maja i Staszica w Częstochowie. Urząd Miasta Częstochowy, Wydział Ochrony Środowiska, Rolnictwa i Leśnictwa, Częstochowa.

For citation: Lechowicz K., Wrońska-Pilarek D., Pilarek Z., Janyszek M. (2016): Verification of a survey of the most valuable trees in the city of Częstochowa. Steciana 20(4): 209-217. doi: $10.12657 /$ steciana.020.022 